\title{
Autocrine effects of PCSK9 on cardiomyocytes
}

\author{
Annemarie Wolf ${ }^{1}$ (D) Hanna Sarah Kutsche ${ }^{1} \cdot$ Rolf Schreckenberg $^{1} \cdot$ Martin Weber $^{1} \cdot$ Ling Li $^{1} \cdot$ Susanne Rohrbach ${ }^{1}$. \\ Rainer Schulz ${ }^{1} \cdot$ Klaus-Dieter Schlüter ${ }^{1}$
}

Received: 6 March 2020 / Accepted: 23 September 2020 / Published online: 10 November 2020

(c) The Author(s) 2020

\begin{abstract}
Proprotein convertase subtilisin kexin type 9 (PCSK9) is in the focus of cardiovascular research due to its role in hepatic low density lipoprotein (LDL) clearance. However, extrahepatic expression of PCSK9 such as in cardiomyocytes and its regulation by oxidized LDL (oxLDL) put notion on extrahepatic effects of PCSK9 as well. This study was aimed to reveal the role of PCSK9 in oxLDL-dependent regulation of cardiomyocyte function. Adult rat and mouse ventricular cardiomyocytes and isolated perfused hearts were used. OxLDL was applied to increase PCSK9 expression in cardiomyocytes. Cell function was analyzed by load-free cell shortening as well as left ventricular developed pressure of isolated hearts. OxLDL decreased shortening in wild-type-derived mouse cardiomyocytes but not in those isolated from PCSK9 knockout mice. Overexpression of human PCSK9 in rat cardiomyocytes reduced shortening in the absence of oxLDL. Addition of recombinant PCSK9 mimicked these effects. In cardiomyocytes, oxLDL induced PCSK9 release into the supernatant. Inhibition of PCSK9 by Pep 2-8 or alirocumab attenuated the oxLDL-induced loss of cardiomyocyte shortening. Cardiomyocytes express surfeit locus protein 4 (SURF-4), a protein required for PCSK9 secretion in human embryonic kidney cells (HEK 293 T), and silencing of SURF-4 reduced the oxLDL effects on cardiomyocytes. In isolated perfused rat hearts PCSK9 inhibition by alirocumab improved the function. In addition, left ventricular function of isolated hearts from PCSK9 knockout mice was increased under basal conditions as well as at $10 \mathrm{~min}$ and $120 \mathrm{~min}$ of reperfusion following $45 \mathrm{~min}$ of ischemia. Collectively, the data show that cardiomyocytes express and release PCSK9 that acts in an autocrine way on cardiomyocytes and impairs their function.
\end{abstract}

Keywords PCSK9 - Cardiomyocytes · Cardiac function · oxLDL · Cardiovascular disease

\section{Introduction}

Proprotein convertase subtilisin kexin type 9 (PCSK9) acts as a negative regulator of the low-density lipoprotein (LDL) receptor in the liver and therefore increases serum LDL cholesterol (LDL-C) [13]. Since hypercholesterolemia is still one of the main risk factors for cardiovascular disease (CVD) [22] and CVD mortality [1], PCSK9 evolved as a new target in the treatment of hypercholesterolemia [6].

Electronic supplementary material The online version of this article (https://doi.org/10.1007/s00395-020-00824-w) contains supplementary material, which is available to authorized users.

Annemarie Wolf

Annemarie.Wolf@physiologie.med.uni-giessen.de

1 Institute of Physiology, Justus-Liebig-University Giessen, Aulweg 129, 35392 Gießen, Germany
Given that subjects with a loss of function mutation of PCSK9 gene show an additional cardiovascular protection independent of LDL-C lowering [4, 7, 19], a different role of PCSK9 in the cardiovascular system has been suggested. Whereas distinct extrahepatic functions of PCSK9 have already been described [31], a direct effect of PCSK9 on cardiac function is still a matter of debate [3].

Previously, we could demonstrate that terminally differentiated ventricular rat cardiomyocytes constitutively express PCSK9 [28]. Furthermore we found that oxLDL, which also plays a pivotal role in the pathophysiology of cardiovascular disease [11, 35], impaired cardiomyocyte function in a PCSK9-dependent way. However, the mechanism by which PCSK9 is involved in this process remained elusive. Nevertheless, oxLDL increased the expression of PCSK9 in cardiomyocytes and silencing of PCSK9 in cardiomyocytes attenuated oxLDL-dependent effects on cell shortening [28]. This might indicate either, that intracellular PCSK9 affects 
cell function or that cardiomyocytes release PCSK9 which then affects the function of cardiomyocytes.

Therefore, we used isolated cardiomyocytes from rats and mice to clarify whether modification of intracellular or extracellular PCSK9 is involved in oxLDL effects on cardiomyocyte and/or cardiac function.

\section{Material and methods}

\section{Materials}

OxLDL (human high oxidized low density lipoprotein), Low-oxidized LDL and LDL was produced by KB Kalen Biomedical, Montgomery Village, USA and purchased from Biotrend Chemikalien, Cologne, Germany. OxLDL stock solution was stored at $4{ }^{\circ} \mathrm{C}$ and used within six weeks. Human recombinant PCSK9 (hPCSK9) was purchased from Cayman Chemical, Michigan, USA. Malondialdehyde-modified human serum albumin (MDA-HSA) was produced by Cell Biolabs, Inc., California, USA and purchased from Biotrend Chemikalien.

\section{Animals}

Adult Wistar rats (175-225 g) and C57BL6/JR (25-35 g) were ordered from Janvier Labs (Le Genest Saint Isles, France). PCSK9 knockout mice (B6;129S6Pcsk $\left.9^{\text {tm } 1 \mathrm{Jdh}}\left(\mathrm{PCSK}^{---}\right), 25-30 \mathrm{~g}\right)$ and appropriate controls (B6129SF2/J (PCSK9 ${ }^{+/+}$), 8-9 weeks old) were supplied from The Jackson Laboratory (Maine, USA) with consent of the University of Texas Southwestern Medical Center. Mice and rats were housed according to the Guide for the Care and Use of Laboratory Animals (NIH Publication No. 85-23, revised 1996). All protocols were approved by the JustusLiebig-University Giessen (permission number: 666_M and 561_M). In this study only male animals were used, to avoid the effect of sex on experiments.

\section{Isolation and cultivation of cardiomyocytes}

Ventricular heart muscle cells were isolated from rats and mice as described previously [5, 25]. In brief, rats or mice have been sacrificed under deep anesthesia (isoflurane 5\%) before the heart was excised and transferred to ice-cold saline. Thereafter the aorta was cannulated and the heart was connected to a Langendorff perfusion system where it was perfused with Powell medium $(\mathrm{NaCl} 110 \mathrm{mM}, \mathrm{KCl}$ $2.5 \mathrm{mM}, \mathrm{KH}_{2} \mathrm{PO}_{4} 1.2 \mathrm{mM}, \mathrm{MgSO}_{4} \times 7 \mathrm{H}_{2} \mathrm{O} 1.2 \mathrm{mM}$, Hepes $25 \mathrm{mM}, \mathrm{D}(+)$-glucose-monohydrate $10 \mathrm{mM}$, pH adjusted to 7.4$)$, that contained collagenase $(25 \mathrm{mg} / \mathrm{ml}, 265 \mathrm{u} / \mathrm{mg}$, Worthington Biochemicals, Lakewook, USA) and $\mathrm{CaCl}_{2}$ $(25 \mu \mathrm{M})$, for $25 \mathrm{~min}$ at $37^{\circ} \mathrm{C}$. Thereafter, ventricular tissue was minced and incubated in the abovementioned solution for another $5 \mathrm{~min}$ at $37^{\circ} \mathrm{C}$. The remaining cell solution was filtered through a $200-\mu \mathrm{m}$ nylon mesh. The filtered material was resuspended in Powell medium, centrifuged and after a stepwise increase in calcium concentration finally transferred to culture medium (Medium 199, supplemented with creatine, carnitine, taurine, and $2 \%$ penicillin-streptomycin, Biochrom). Cells were plated onto culture dishes $(35 \mathrm{~mm})$ which were precoated with $4 \%(v / v)$ fetal calf serum (FCS) (PAA, BioPharm). After one hour cell culture medium was refreshed and PCSK9 $(200 \mathrm{ng} / \mathrm{ml})$, oxLDL $(5-20 \mu \mathrm{M})$, Pep 2-8 $(10 \mu \mathrm{M})$, alirocumab $(1.5 \mathrm{mg} / \mathrm{ml})$ or combinations thereof were added (as indicated) to the culture medium. Cells were then cultured under serum-free conditions for $24 \mathrm{~h}$ at $37^{\circ} \mathrm{C}$ in the above mentioned medium. Where indicated, small interfering RNA (siRNA) directed against SURF-4 (final concentration $0.05 \mu \mathrm{M}$ ) was added $6 \mathrm{~h}$ before administration of oxLDL $(5-20 \mu \mathrm{M})$ to the culture medium. SiRNA was purchased from Qiagen, Venlo, Netherland.

\section{Adenoviral infection of cardiomyocytes and HepG2 cells}

Isolated cardiomyocytes were infected with hPCSK9. Therefore an adenoviral plasmid with the insert of hPCSK9 gain of function mutation D374Y (pAd/CMV/V5 hPCSK9, Addgene, Massachusettes, USA) was generated by gateway cloning $[15,17]$ (pENTR ${ }^{\mathrm{TM}}$ Directional TOPO®Cloning Kit,Thermo Fisher Scientific, Massachusettes, USA). An adenoviral plasmid with the insert of LacZ was generated for control (pAd/CMV/V5 LacZ, Addgene, Massachusettes, USA). HEK 293 A cells have then been transfected with these adenoviral plasmids (hPCSK9, LacZ). The adenovirus produced by HEK 293 A cells was collected and used to infect adult ventricular cardiomyocytes as well as HepG2 cells with hPCSK9 and LacZ, respectively. The supernatants of HepG2 cells that contained hPCSK9 or LacZ were collected $72 \mathrm{~h}$ after infection, centrifuged $(6000 \times g)$ and then stored at $-80^{\circ} \mathrm{C}$. Cardiomyocytes have been infected with hPCSK9/LacZ or incubated with supernatants of HepG 2 cells over 24 h before load-free cell shortening was determined.

\section{Cell shortening}

Cells were stimulated via two $\mathrm{AgCl}$ electrodes with biphasic electrical stimuli composed of two equal but opposite rectangular $50 \mathrm{~V}$ stimuli of $5 \mathrm{~ms}$ duration as described before [18]. Cells were stimulated at $2 \mathrm{~Hz}$ frequency. Four signals were registered from each cell. The mean of these four measurements was used to define the contractile responsiveness of a given cell. Cell lengths were measured at a rate of $500 \mathrm{~Hz}$ via a line camera. Cells were used in M199 with an 
extracellular calcium concentration of $1.25 \mathrm{mM}$. Data are expressed as $\Delta \mathrm{L} / \mathrm{L}(\%)$ in which the shortening amplitude $(\Delta \mathrm{L})$ is expressed as percent of the diastolic cell length $(\mathrm{L})$. Furthermore, maximal contraction and relaxation velocity $(\mu \mathrm{m} / \mathrm{s})$ were analyzed.

\section{ELISA}

Release of PCSK9 into the supernatant from cardiomyocytes as well as from hPCSK9 overexpressing HepG2 cells was quantified by the use of a commercial available kit purchased by Cusabio Biotech Co. China (Rat PCSK9 ELISA kit) and Cloud-Clone Corp. Texas, USA (Human PCSK9 ELISA).

\section{Langendorff perfusion of hearts isolated from rat our mouse}

The left ventricular function of isolated rat hearts was evaluated as described before [30]. Therefore hearts were excised as mentioned above and attached to a 16-gauge needle. The cannulated heart was then connected to a Langendorff perfusion system where it was perfused retrograde with an oxygenated saline buffer $\left(\mathrm{NaCl} 140 \mathrm{mM}, \mathrm{NaHCO}_{3} 24 \mathrm{mM}, \mathrm{KCl}\right.$ $2.7 \mathrm{mM}, \mathrm{NaH}_{2} \mathrm{PO}_{4} 0.4 \mathrm{mM}, \mathrm{MgCl}_{2} 1 \mathrm{mM}, \mathrm{CaCl}_{2} 1.8 \mathrm{mM}$ and glucose $5.0 \mathrm{mM}, \mathrm{pH}$ 7.4). A polyvinylchloride balloon, which was connected to a pressure transducer, was carefully inserted into the left ventricle to assess left ventricular pressure (LVDP), dp/dt max as well as dp/dt min.

To validate a possible function of PCSK9 on left ventricular function isolated hearts were perfused with a monoclonal antibody against PCSK9 (alirocumab used in a concentration of $750 \mu \mathrm{g}$ ).

In addition hearts from PCSK9 knockout and control mice were prepared and attached to an Aortic Cannula $(\varnothing$ $1 \mathrm{~mm}$, Hugo Sachs Elektronik-Harvard Apparatus, March, Germany). The cannulated heart was then connected to a Langendorff perfusion system (Hugo Sachs Elektronik-Harvard Apparatus, March, Germany) where it was perfused retrograde with a $37^{\circ} \mathrm{C}$ warm modified Krebs Henseleit buffer ( $\mathrm{NaCl} 118 \mathrm{mM}, \mathrm{KCl} 4.7 \mathrm{mM}, \mathrm{MgSO}_{4} 0.8 \mathrm{mM}, \mathrm{KH}_{2} \mathrm{PO}_{4}$ $1.2 \mathrm{mM}$, G/glucose $5 \mathrm{mM}, \mathrm{CaCl}_{2} 2.5 \mathrm{mM}, \mathrm{NaHCO}_{3} 25 \mathrm{mM}$, pyruvate $1.9 \mathrm{mM}$; pH 7.4; sterile-filtered with an $0.2 \mu \mathrm{m}$ filter; saturated with $95 \%$ oxygen and $5 \%$ carbogen). The perfusion pressure was adjusted to $70 \mathrm{mmHg}$ (transduced by a Replacement Transducer Head for APT300 Pressure Transducer, Hugo Sachs Elektronik-Harvard Apparatus) and kept constant during the whole experiment. A small ballon (built up from a cling-film), which was connected to a pressure transducer (Combitrans 1-fach Set Mod.II University Giessen, B. Braun, Melsungen, Germany), was carefully inserted into the left ventricle and inflated up to $12-14 \mathrm{mmHg}$ (end diastolic pressure) to assess left ventricular function. Additionally the hearts were paced at $600 \mathrm{bpm}$ to ensure a stable heart rate. Left Ventricular Pressure (LVPD = systolic pressure-diastolic pressure) was determined as well as dLVP/ $\mathrm{dt}_{\max }$ and $\mathrm{dLVP} / \mathrm{dt}_{\min }$. For the ischemia/reperfusion protocol: After stabilization phase $(5 \mathrm{~min})$ the perfusion and pacing was switched off for $45 \mathrm{~min}$ to generate a no flow ischemia. Thereafter the heart was reperfused for another $120 \mathrm{~min}$.

\section{RNA Isolation and qRT-PCR}

RNA was isolated from liver samples and isolated cardiomyocytes using peqGold Trifast (peqlab, Biotechnologie GmbH, Erlangen, Germany) according to manufacturer's protocol. To avoid genomic DNA contamination, samples were treated with DNase (1U/ $\mu \mathrm{g}$ RNA; Invitrogen, Karslruhe, Germany) for $15 \mathrm{~min}$ at $37^{\circ} \mathrm{C}$. The Reverse Transcription of RNA $(1 \mu \mathrm{g} / 10 \mu \mathrm{l})$ into cDNA was performed with Superscript RNase reverse transcriptase $(200 \mathrm{U} / \mu \mathrm{g}$ RNA; Invitrogen) and oligo dTs at $37^{\circ} \mathrm{C}$ for $60 \mathrm{~min}$. Quantitative Real-Time PCR was performed using the Icycler MyiQ ${ }^{\circledR}$ detection systems (Bio-Rad, Munich, Germany) in combination with IQ SYBR green real-time supermix (BioRad, Munich, Germany). Primer for surfeit locus protein-4 (SURF-4) and beta-2-microglobulin (B2M) (Table 1) were used and quantification was performed applying the $\Delta \Delta \mathrm{Ct}$ method [20].

\section{Western Blot}

Isolated cardiomyocytes were incubated with cell lysis buffer (Cell Signaling, Technology, Frankfurt, Germany) as described before [29]. Samples were treated 1:1 with Leammli buffer (Sigma-Aldrich, Taufkirchen, Germany) and loaded ( $\sim 100 \mu \mathrm{g}$ protein) on a $10 \%$ SDS-PAGE (Life Technology, Darmstadt, Germany). Following electrophoresis proteins were subsequently transferred to a nitrocellulose membrane. Anti-PCSK9 polyclonal antibody produced in goat (\#AF3985, R\&D Systems, Minnesota, USA) was used to detect the expression of PCSK9 protein. Glyceraldehyde 3-phosphate dehydrogenase (GAPDH) served as
Table 1 List of primer used in this study

\begin{tabular}{lll}
\hline Gene & Forward & Reverse \\
\hline B2M & GCCGTCGTGCTTGCCATTC & CTGAGGTGGGTGGAACTGAGAC \\
SURF-4 & ATTTCGCCGACCAGTTCCTT & CAGGTAACCACAGCTCCAGG \\
PCSK9 (human) & CACCATGGGCACCGTCAGCTCCAG & AAACTGGAGCTCCTGGGAGGCC \\
PCSK9 (mouse) & TTGAACAAACTGCCCATCGC & CCCAACAGGTCACTGCTCAT \\
\hline
\end{tabular}


loading control. Detection of GAPDH was performed using anti-GAPDH monoclonal antibody produced in mouse (\#CB1001, Calbiochem®, Schwalbach, Germany). Secondary antibodies were purchased from Dako (now Agilent Technologies, Santa Clara, USA).

\section{Statistics}

Data are expressed as means $\pm \mathrm{SD}$, indicated in the legend of the figures. The statistical comparison of two groups was performed by two-sided- $t$-test, if normal distribution of samples could be verified, otherwise Mann-Whitney- $U$ test was applied. Comparison of more than two groups was performed with one-way following a post hoc analysis with the Student-Newman-Keuls test. $p$ levels $\leq 0.05$ were regarded as significant and indicated as an asterisk or as indicated in the figure's legend. Figures were generated with Graph Pad Prism 8.

\section{Results}

\section{OxLDL-induced reduction of cardiomyocyte cell-shortening requires PCSK9}

To investigate whether endogenously expressed PCSK9 alters cell shortening of adult ventricular cardiomyocytes, we isolated adult ventricular cardiomyocytes from $\mathrm{PCSK}^{-/-}$- as well as $\mathrm{PCSK}^{+/+}$-mice. Comparison between both strains revealed no obvious difference (Fig. 1). Cardiomyocytes from both strains were cultivated under serum-free conditions and also incubated for $24 \mathrm{~h}$ with oxLDL $(5 \mu \mathrm{M})$. Thereafter function was measured by load-free cell shortening. While the incubation with oxLDL $(5 \mu \mathrm{M})$ led to a significant decrease of relative cell shortening (Fig. 1a) as well as contraction (Fig. 1b) and relaxation velocities (Fig. 1c) in $\mathrm{PCSK}^{+/+}$-cardiomyocytes, this effect was absent in cardiomyocytes isolated from PCSK $9^{-/-}$-mice (Fig. 1a-c). Instead, there was an increase in contraction and relaxation velocity in cardiomyocytes that lacked PCSK9 in the presence of oxLDL (Fig. $1 b+c)$.

\section{Effect of PCSK9 overexpression on load free cell shortening of cardiomyocytes}

Given the above findings we hypothesized that PCSK9 affects cardiomyocyte function independent from oxLDLstimulation. Adult ventricular cardiomyocytes (from rats) were infected with an adenovirus bearing hPCSK9 for $24 \mathrm{~h}$ to induce PCSK9 overexpression in cardiomyocytes. The control group was infected with an adenovirus bearing LacZ. To proof the successful transfection of cardiomyocytes, the protein expression of PCSK9 was analyzed by Western
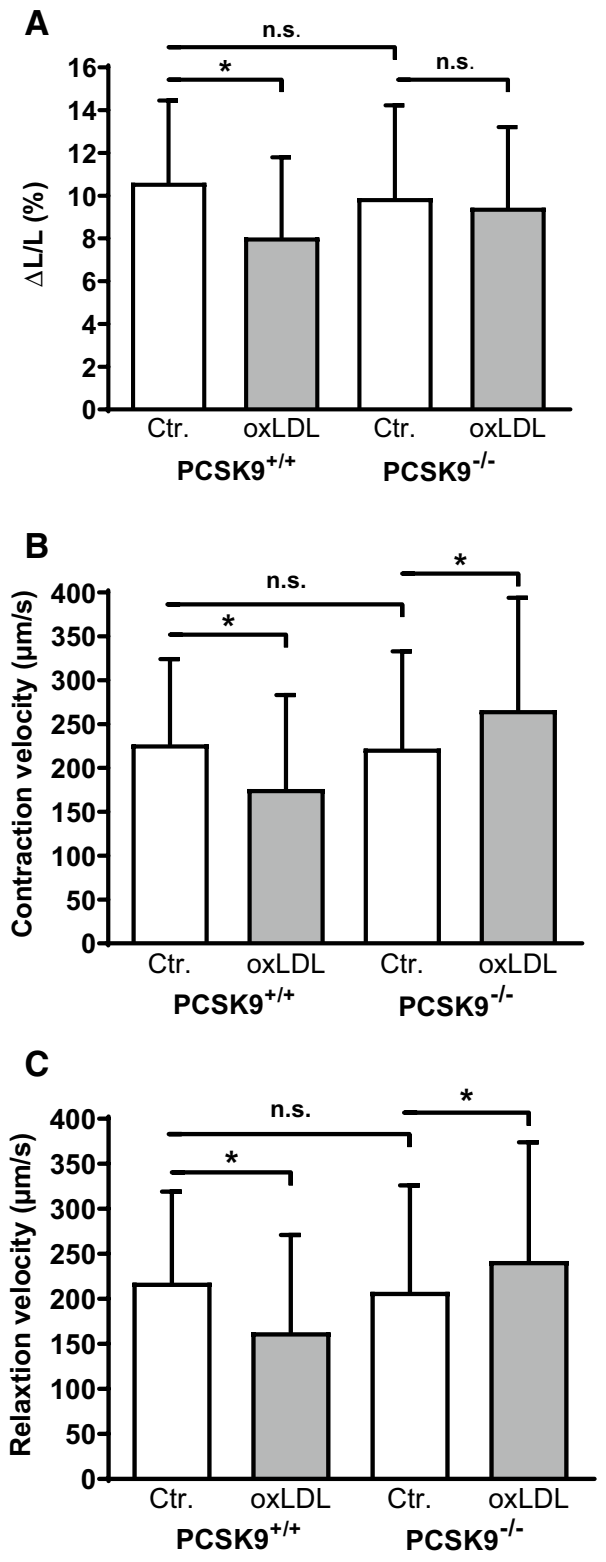

Fig. 1 Effect of oxLDL on load-free cell shortening of isolated cardiomyocytes derived from $\mathrm{PCSK} 9^{-/-}$- and $\mathrm{PCSK} 9^{+/+}$-mice. Serumfree cultured adult ventricular cardiomyocytes were exposed to $5 \mu \mathrm{M}$ oxLDL for $24 \mathrm{~h}$. Load free cell shortening (cells were paced at $2 \mathrm{~Hz}$ ) is expressed (a) as $\Delta \mathrm{L} / \mathrm{L}(\%)$, (b) contraction velocity $(\mu \mathrm{m} / \mathrm{s})$ (c) and relaxation velocity $(\mu \mathrm{m} / \mathrm{s})$ of $222\left(\mathrm{PCSK}^{+/+}\right.$, Control), 126 (PCSK9 $^{+/+}$, oxLDL), 162 (PCSK9 $^{-/-}$, Control) and 134 (PCSK9 $^{-/-}$, oxLDL) cells (14-25 independent experiments with an intraassay variability of $p>0.05$ ). Statistical analysis was performed by MannWhitney test. $* p \leq 0.05$, n.s. not significant. Data are mean \pm SD

Blot (Fig. 2a). In the lysates of cardiomyocytes that had been infected with hPCSK9 9 more prominent band of prepro-PCSK9 $(\sim 100 \mathrm{kDa})$ as well as of the $\sim 72 \mathrm{kDa}$ form of PCSK9 appeared, that were less intense in controls as well as in cardiomyocytes infected with LacZ (Fig. $2 \mathrm{a}+\mathrm{b}$ ). After $24 \mathrm{~h}$ of adenoviral infection cardiomyocyte function was 
Fig. 2 Infection of cardiomyocytes with human PCSK9. Serum-free cultured adult rat ventricular cardiomyocytes were infected with hPCSK9. Infection of cardiomyocytes with LacZ served as control. After $24 \mathrm{~h}$, load free cell shortening was measured (cells paced at $2 \mathrm{~Hz}$ ). a Representative immunoblot indicating the successful transfection of cardiomyocytes with hPCSK9. b Quantification of Western Blot shown in (a). c Load free cellshortening expressed as $\Delta \mathrm{L} / \mathrm{L}$ $(\%),(\mathbf{d})$ contraction velocity $(\mu \mathrm{m} / \mathrm{s})(\mathbf{e})$ and relaxation velocity $(\mu \mathrm{m} / \mathrm{s})$ of 89 (LacZ) and 90 (PCSK9) cells (10 independent experiments with intraassay variability $p>0.05)$. Statistical analysis was performed by Mann-Whitney test. $* p \leq 0.05$. Data are mean \pm SD
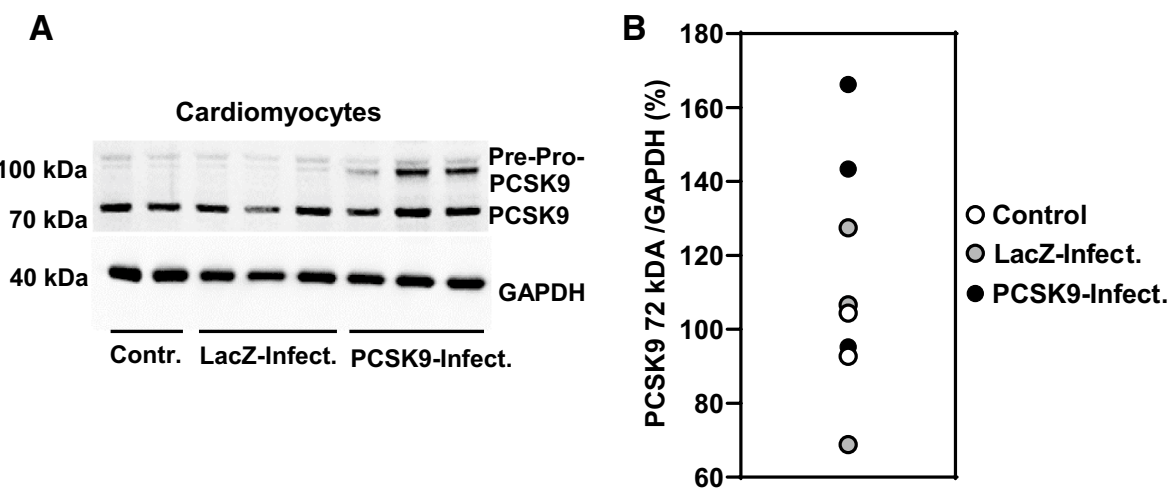

C

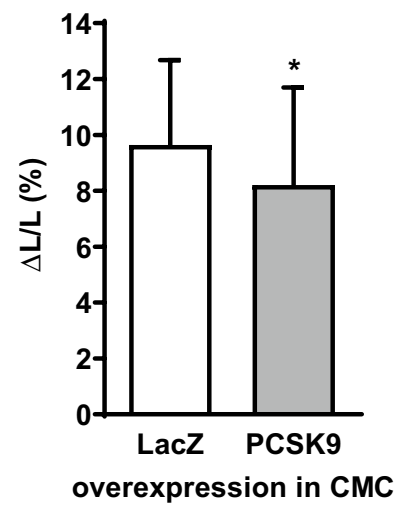

D

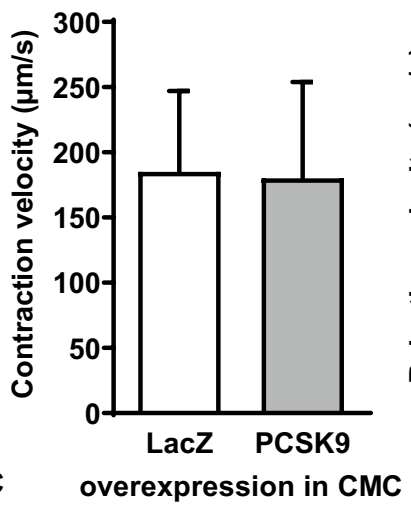

E

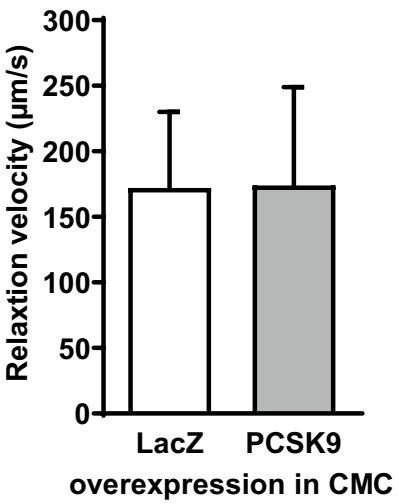

measured by load-free cell shortening (Fig. 2c, d). While relative cell shortening (Fig. 2c) was significantly decreased in cardiomyocytes that had been infected with hPCSK9, neither relaxation velocity (Fig. 2e) nor contraction velocity (Fig. 2d) were impaired due to the infection with hPCSK9 $(* p \leq 0.05)$.

\section{Effect of increased extracellular PCSK9-levels on cardiomyocyte function}

To distinguish between the effect of PCSK9 overexpression and an increase in extracellular PCSK9 on cardiomyocyte function, we incubated adult rat ventricular cardiomyocytes with supernatants derived from PCSK9 or LacZ overexpressing HepG2 cells. Therefore HepG2 cells were infected with hPCSK9 or LacZ. Cardiomyocytes were then incubated with PCSK9 (122.64 $\pm 6.23 \mathrm{ng} / \mathrm{ml}, n=4)$ or LacZ containing supernatants for $24 \mathrm{~h}$ before load-free cell shortening was measured (Fig. 3). The incubation of cardiomyocytes with HepG2 supernatants containing elevated levels of PCSK9 led to a significant decrease of cell shortening compared to the presence of LacZ enriched supernatants (Fig. 3b). Furthermore contraction velocity (Fig. 3c) as well as relaxation velocity (Fig. 3d) were significantly reduced in the presence of HepG2 derived PCSK9-supernatants ( $\left.{ }^{*} p \leq 0.05\right)$.

\section{Effects of recombinant PCSK9, Pep 2-8 and alirocumab on cardiomyocyte function}

To validate the effects of extracellular PCSK9 on cardiomyocyte function and exclude any unspecific effect of HepG2 supernatants we incubated cells with purified recombinant PCSK9 for $24 \mathrm{~h}$. At first, a concentrationeffect curve was performed to identify the most effective concentration $(2 \mu \mathrm{g} / \mathrm{ml}, 200 \mathrm{ng} / \mathrm{ml}$ and $20 \mathrm{ng} / \mathrm{ml})$ of PCSK9. After $24 \mathrm{~h}$ function was determined by load-free cell shortening. Relative cell shortening in these cells was reduced from $9.81 \pm 3.12 \%$ to $6.29 \pm 3.43 \%(2 \mu \mathrm{g} /$ $\mathrm{ml}), 7.76 \pm 3.99 \%(200 \mathrm{ng} / \mathrm{ml})$ and $8.78 \pm 3.56 \%(20 \mathrm{ng} /$ $\mathrm{ml}$ ) respectively ( $n=54$ cells). In all further experiments a PCSK9 concentration of $200 \mathrm{ng} / \mathrm{ml}$ was applied. In the presence of recombinant PCSK9 a significant decline in cell shortening (Fig. 4a) as well as contraction (Fig. 4b) and relaxation velocities (Fig. 4c) in adult ventricular cardiomyocytes $(* p \leq 0.05)$ was observed. In addition, the PCSK9 inhibitor Pep 2-8 $(10 \mu \mathrm{M})$ and the monoclonal antibody against PCSK9 (alircoumab, Sanofi, $1.5 \mathrm{mg} / \mathrm{ml}$ ) antagonized the negative effect of PCSK9 on cellular function, while neither Pep 2-8, nor alirocumab had any effect on basal cardiomyocyte function, expressed as relative cell shortening (Fig. 4a), contraction (Fig. 4b) and relaxation velocities (Fig. 4c). 
Fig. 3 Effect of hPCSK9 incubation on cell shortening of cardiomyocytes. Serum-free cultured adult rat ventricular cardiomyocytes were incubated for $24 \mathrm{~h}$ with supernatants derived from $\mathrm{HepG} 2$ cells that have been infected with hPCSK 9 or LacZ for $72 \mathrm{~h}$. a PCSK9 concentration in supernatant of HepG2 cells infected with LacZ or PCSK9 was determined by ELISA $(n=4)$. b Load free cell shortening is expressed as $\Delta \mathrm{L} / \mathrm{L}(\%),($ c) contraction velocity $(\mu \mathrm{m} / \mathrm{s})(\mathbf{d})$ and relaxation velocity $(\mu \mathrm{m} / \mathrm{s})$ of 160 (LacZ) and 180 (PCSK9) cells (14 independent experiments with intraassay variability of $p>0.05$ ). Cells were paced at $2 \mathrm{~Hz}$. Statistical analysis was performed by Mann-Whitney test. $* p \leq 0.05$. Data are mean \pm SD
A

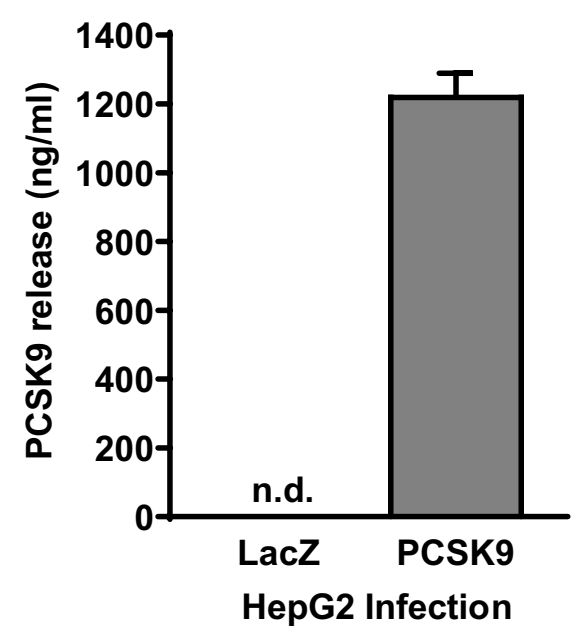

C

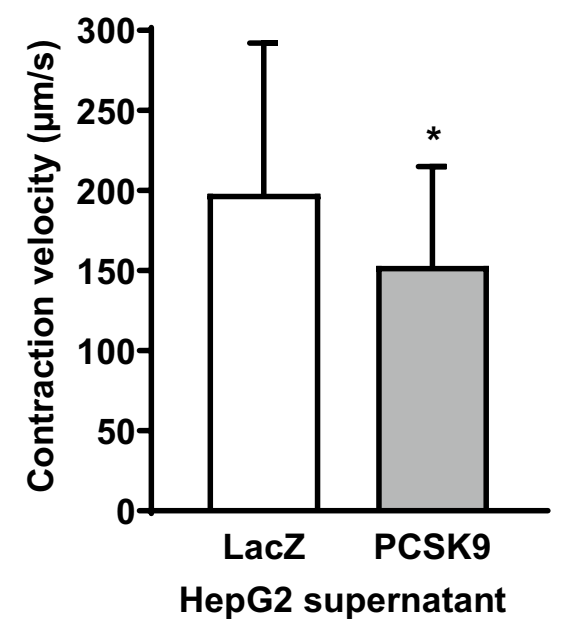

B

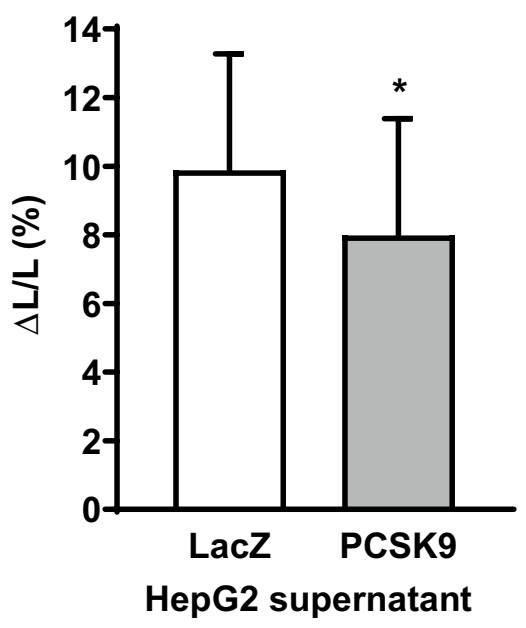

D

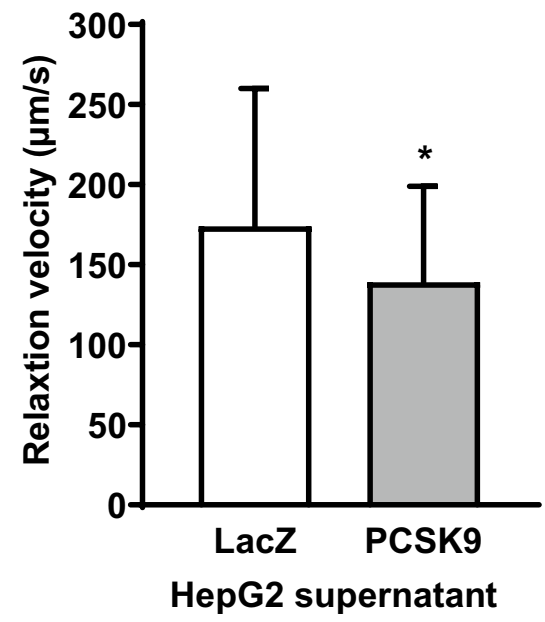

\section{OxLDL-induced reduction of cell shortening is accombined by the release of PCSK9 from cardiomyocytes}

To evaluate if oxLDL might induce PCSK9 release from cardiomyocytes we measured the PCSK9 concentration in supernatants of cardiomyocytes that had been incubated with oxLDL (10 or $20 \mu \mathrm{M}$ ) for $24 \mathrm{~h}$ (Fig. 6a). There was a concentration-dependent increase of PCSK9 in the supernatants of cardiomyocytes. The mean PCSK9 concentration in supernatants of controls was $565.8 \pm 219.7 \mathrm{pg} / \mathrm{ml}$. As SURF-4 is known to play a crucial role in secretion of PCSK9 in HEK239 cells [10] we screened adult ventricular cardiomyocytes for SURF-4 expression by qPCR. In cardiomyocytes (CMC), the threshold cycle (Ct) of SURF-4 amplification (normalized to the $\mathrm{Ct}$ of $\mathrm{B} 2 \mathrm{M}$ amplification) (Fig. 5a) was $6.49 \pm 0.6$ while $\Delta$ Ct of SURF-4 amplification in liver samples was $4.89 \pm 0.07$. To test if the oxLDL-induced increase in PCSK9 release and therefore the impaired cardiomyocyte function might require SURF-4, we silenced SURF-4 by administration of siRNA (SURF-4 mRNA in cardiomyocytes was reduced to $69.75 \pm 21.83 \%$ of controls by incubation with siRNA) prior to incubation with oxLDL. Silencing of SURF-4 resulted in a decreased release of PCSK9 from cardiomyocytes (Fig. 5b) under basal conditions as well as in the presence of oxLDL $(20 \mu \mathrm{M})$ (Fig. 6b).

In addition silencing of SURF-4 increased cell shortening (expressed as $\Delta \mathrm{L} / \mathrm{L}(\%)$, contraction and relaxation velocity $(\mu \mathrm{m} / \mathrm{s}))$ of cardiomyocytes that showed reduced function due to incubation with oxLDL (Fig. 6c-e).

\section{Effects of oxLDL on cardiomyocyte cell shortening in the presence of Pep 2-8 or alirocumab}

To address the question if oxLDL leads to an increased release of PCSK9 from cardiomyocytes and therefore to a reduction of 


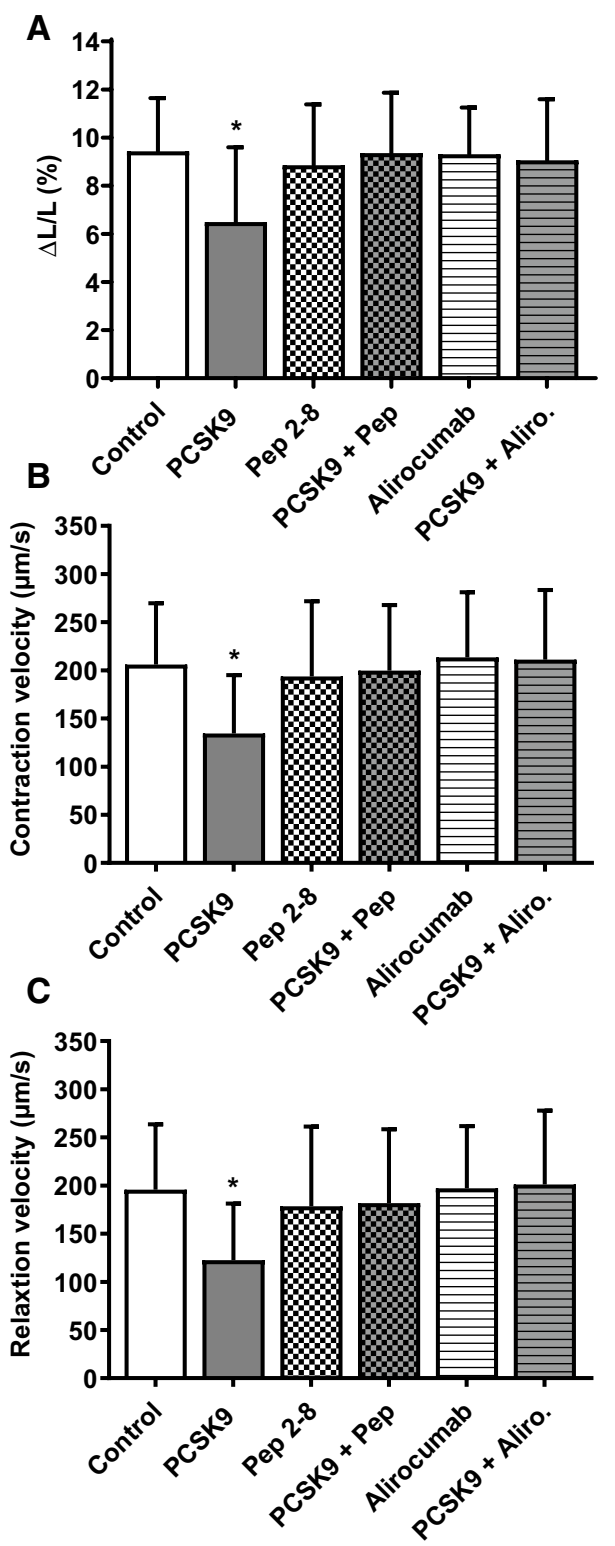

Fig. 4 Effect of recombinant PCSK9 on cell shortening in the presence of Pep 2-8 or alirocumab. Adult rat ventricular cardiomyocytes were cultured under serum-free conditions and incubated with recombinant PCSK9 $(200 \mathrm{ng} / \mathrm{ml})$, the PCSK9 inhibitor Pep 2-8 $(10 \mu \mathrm{M})$, the monoclonal PCSK9 antibody alirocumab $(1.5 \mathrm{mg} / \mathrm{ml})$ and combinations thereof. After $24 \mathrm{~h}$ load free cell shortening was measured (cells were paced at $2 \mathrm{~Hz}$ ) and expressed as (a) $\Delta \mathrm{L} / \mathrm{L}(\%)$, (b) contraction velocity $(\mu \mathrm{m} / \mathrm{s})$ and c relaxation velocity $(\mu \mathrm{m} / \mathrm{s})$ of Control $=278$, PCSK9 $=262$, Pep $2-8=114$, PCSK9 + Pep $=111$, Alirocumab $=147$ and PCSK9 + Aliro. $=48$ cells $(5-20$ independent experiments with intraassay variability of $p>0.05)$. Statistical analysis was performed by one-way ANOVA and Student-Newman-Keuls for post hoc analysis. ${ }^{*} p \leq 0.05$ vs. Control, Pep $2-8$, PCSK $9+$ Pep, Alirocumab and PCSK9 + Aliro. Data are mean \pm SD

cardiomyocyte function, we incubated isolated cardiomyocytes with oxLDL $(20 \mu \mathrm{g} / \mathrm{ml})$ and oxLDL in combination with Pep $2-8(10 \mu \mathrm{M})$ or alirocumab $(1.5 \mathrm{mg} / \mathrm{ml})$. After $24 \mathrm{~h}$ cell function was measured by load-free cell shortening (Fig. 7a-c).
While oxLDL led to a significant $(* p \leq 0.05)$ decrease of relative cell shortening (Fig. 7a), as well as contraction (Fig. 7b) and relaxation velocities (Fig. 7c), the oxLDL effect on cardiomyocyte function was strongly reduced when incubating the cells concurrently with Pep 2-8 or alirocumab. Both PCSK9 antagonists had no effect on cardiomyocyte function per se (Fig. 4a-c). We further evaluated if the effect using oxLDL depends on the level of oxidation. Therefore we measured load-free cell shortening of cardiomyocytes incubated for $24 \mathrm{~h}$ with non-oxidized LDL, low oxidized LDL, or high oxidized LDL. Neither LDL nor low oxidized LDL had an effect on load free cell shortening of cardiomyocytes at a concentration at which high oxidized LDL already depressed cell function (Supp. Figure 1B). Also an oxidatively modified non-lipid plasma protein, such as MDA-modified HSA, had no effect on cell-shortening (Supp. Figure 1A).

\section{Alirocumab affects left ventricular function of isolated perfused hearts}

Finally, we investigated the effect of alirocumab on basal left ventricular function to exclude that the observed cardiomyocyte effects of PCSK9 can be neglected in vivo. Isolated hearts from adult rats were used and left ventricular function was assessed. Mean PCSK9 concentration in the perfusates collected during the stabilization phase was $1443 \pm 885 \mathrm{pg} /$ $\mathrm{ml}(n=6)$. Addition of alirocumab $(750 \mu \mathrm{g} / \mathrm{ml})$ to the perfusion buffer (for $10 \mathrm{~min}$ ) increased left venctricular developed pressure (LVDP, mmHg) (Fig. 8a) as well as $\mathrm{dP} / \mathrm{dt}_{\max }$ (Fig. 8 b) (mmHg/s) and dP/dt ${ }_{\text {min }}(\mathrm{mmHg} / \mathrm{s})$ (Fig. $8 \mathrm{c}$ ).

\section{PCSK9 knockout improves left ventricular function of isolated mice hearts basal and during reperfusion}

Moreover hearts were isolated from adult PCSK9 knockout and control mice to asses left ventricular function. Mean LVDP $(\mathrm{mmHg}), \mathrm{dLVP} / \mathrm{dt}_{\max }(\mathrm{mmHg} / \mathrm{s})$ and $\mathrm{dLVP} / \mathrm{dt}_{\min }$ $(\mathrm{mmHg} / \mathrm{s})$ (Fig. 9) were significantly increased in hearts from PCSK9 knockout mice $(* p \leq 0.05)$.

In addition PCSK9 mRNA was upregulated in left ventricles with ischemia/reperfusion (I/R) injury (ex vivo) (Fig. 10a). To evaluate the role of cardiac PCSK9 in myocardial I/R injury, we performed an I/R protocol with isolated hearts of PCSK9 knockout mice. LVDP (\%) of PCSK9 knockout hearts was significantly increased during reperfusion (Fig. 10b) compared to the LVDP (\%) of controls.

\section{Discussion}

From our previous study it was already known that oxLDL induced the expression of PCSK9 in cardiomyocytes and reduced cardiomyocyte' function in a PCSK9-dependent 
A

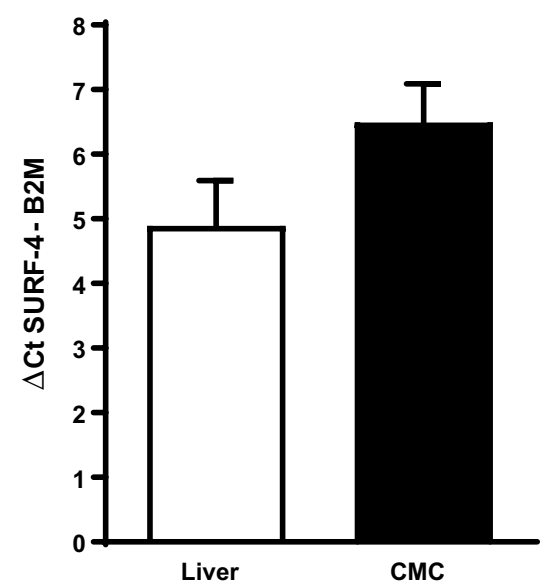

Fig. 5 Silencing of SURF-4 in cardiomyocytes affects PCSK9 release. a Expression of SURF-4 in liver and cardiomyocytes (CMC) of adult Wistar rats. Threshold cycle $(\mathrm{Ct})$ of SURF-4 amplification, normalized to the mean $\mathrm{Ct}$ of $\mathrm{B} 2 \mathrm{M}$-amplification $(\Delta \mathrm{Ct}) . n=3$ (liver) and $n=10$ (CMC). b Adult ventricular cardiomyocytes were culti-

way [28]. To further study the mechanism behind this effect, the current study adds five new findings: (1) oxLDL reduces cell shortening in mice and rat cardiomyocytes. (2) OxLDL induces a paracrine effect of PCSK9 that than reduces cardiomyocyte cell shortening. (3) OxLDL leads to an increase in PCSK9 secretion that requires SURF-4 as in HEK293 cells [10]. (4) Antagonism of PCSK9 by monoclonal antibody (alirocumab) leads to an immediate increase in left ventricular function of isolated perfused hearts. (5) Hearts isolated from PCSK9 knockout mice show increased postischemic function. Therefore, cardiomyocyte-derived PCSK9 seems to directly reduce cardiomyocyte and cardiac function, respectively. The data suggest that the aforementioned superior effect of PCSK9 inhibition over cholesterol reduction performed by statins is supported by direct effects on cardiomyocyte-derived PCSK9.

Since its discovery in 2003 [2, 33] PCSK9 has emerged as an important target in the treatment of hyperlipidemia due to its role in hepatic LDL-clearance [6]. Apart from that distinct extrahepatic functions of PCSK9 have been described during the past years [12]. PCSK9 for example regulates the abundance of the epithelial sodium channel in the kidney [34] and is also expressed in pancreatic islets $\beta$ cells where it contributes to glucose tolerance [8, 23]. Moreover studies report that patients with a loss of function mutation in PCSK9 show a cardiovascular protection that is higher than predicted by the associated reduction of LDL-C alone [4, 7, 19]. Therefore a possible direct negative effect of PCSK9 on the cardiovascular system, that is independent of its role in LDL-clearance, could be suggested.

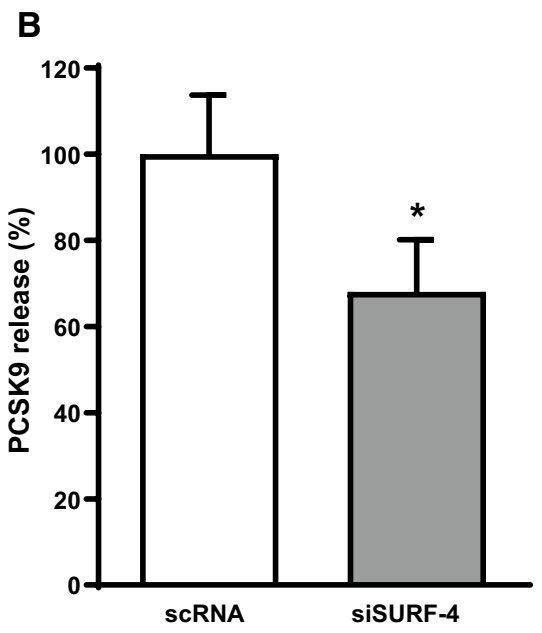

vated under serum-free conditions for $24 \mathrm{~h}$ in the presence of scrambled RNA $(n=4)$ or siRNA targeted against SURF-4 $(n=5)$. PCSK9 release from cardiomyocytes was analyzed by ELISA and normalized to controls (scRNA). Statistical analysis was performed by unpaired $t$ test. $* p \leq 0.05$. Data are mean $\pm \mathrm{SD}$

Recently it was reported that PCSK9 plasma levels are associated with a reduced ejection fraction in patients suffering from ST-segment elevation myocardial infarction [24]. Furthermore a distinct function of cardiomyocyte-derived PCSK9 has only been reported for neonatal mouse cardiomyocytes, where under hypoxic conditions the release of PCSK9 determines autophagy in these cells [9]. Unfortunately this cell type is not directly comparable to terminally differentiated cardiomyocytes and autophagy not directly linked to mechanical function.

In our previous study we demonstrated that terminally differentiated cardiomyocytes isolated from rats constitutively express (mRNA, protein) and release PCSK9 [28]. Meanwhile the expression of PCSK9 in neonatal mouse cardiomyocytes as well as in ischemic mice hearts has been described [9]. In addition we reported that cardiomyocyte-derived PCSK9 is involved in the oxLDL-induced reduction of cardiomyocyte cell shortening [28]. In the current study we could reveal that the oxLDL-induced reduction of cardiomyocyte function requires PCSK9 because this effect was absent in $\mathrm{PCSK}^{-/-}$- but present in PCSK $9^{+/+}$-cardiomyocytes. With these experiments we could demonstrate the PCSK9 mediated oxLDL effect already in two different species (mouse, rat). In addition, we found no difference in basal function of cardiomyocytes from both strains. This supports the view that intracellular PCSK9 is not directly involved in cell function. In addition, only when PCSK9 expression is increased by oxLDL [28] and release is increased by oxLDL (present study) the threshold of extracellular PCSK9 is sufficient to reduce cardiomyocyte shortening. In addition the effect of oxidized LDL seems to depend on the oxidation-level 
A

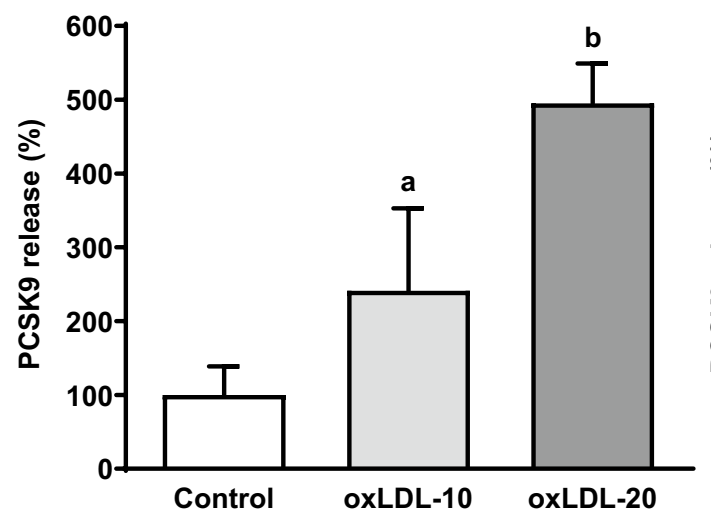

C

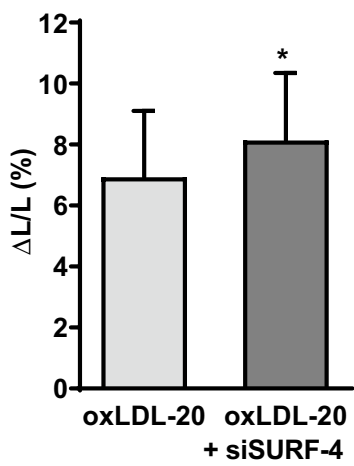

B

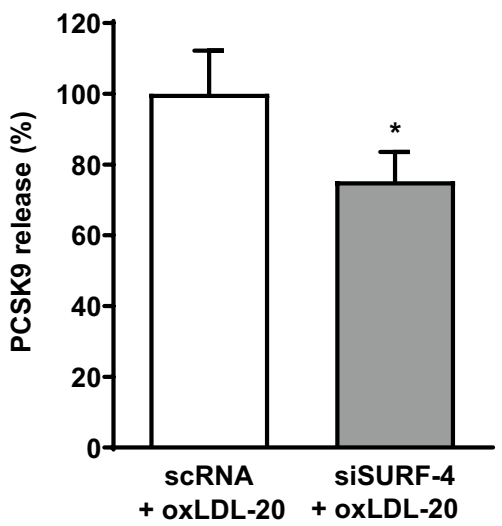

E
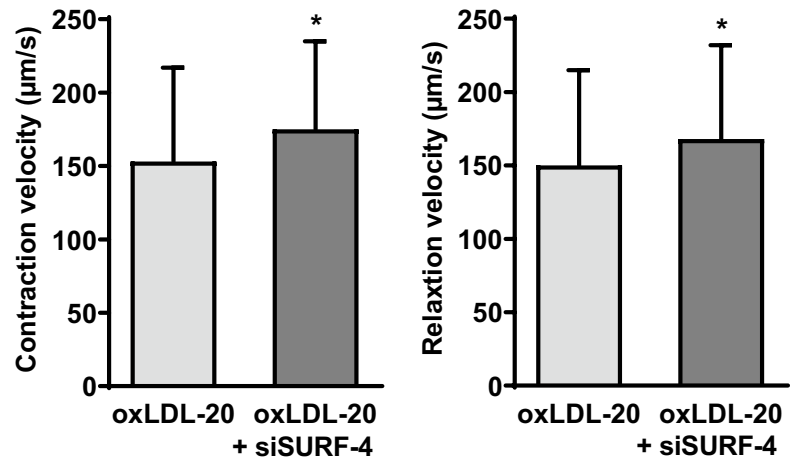

Fig. 6 Participation of SURF-4 on the oxLDL-dependent effect on load free cell shortening of cardiomyocytes. a Adult rat ventricular cardiomyocytes were cultured under serum-free conditions and exposed to 10 or $20 \mu \mathrm{M}$ oxLDL. After $24 \mathrm{~h}$ PCSK 9 concentration $(\mathrm{pg} / \mathrm{ml})$ in the supernatant of these cells was analyzed via ELISA and normalized to controls, expressed as PCSK 9 release (\% of control). Data are mean \pm SD from $n=10$ (control), $n=17$ (oxLDL-10) and $n=4$ (oxLDL-20) independent experiments. Statistical analysis was performed by one-way ANOVA and Student-Newman-Keuls for post hoc analysis. $a<0.05$ vs. control and oxLDL-20, $b<0.05$ vs. control and oxLDL-10. b PCSK9 release from cardiomyocytes (CMC) was quantified by ELISA. Cells were cultivated serum-free and in

of LDL. Furthermore, an oxidatively modified non-lipid plasma protein (MDA-HSA) had no effect on cardiomyocyte cell shortening.

The incubation of cardiomyocytes with supernatants collected from hPCSK9 overexpressing HepG2 cells, led to a significant decline of cardiac function that was absent under control conditions. Furthermore these findings were reproducible by incubation of cardiomyocytes with recombinant PCSK9. Therefore any unspecific effect of HepG2 supernatants on cell shortening can be excluded. The concentration of PCSK9 $(200 \mathrm{ng} / \mathrm{ml})$ used in this study to reduce cardiomyocyte function is comparable with the mean serum PCSK9 concentration found in rats [36] and humans [27]. the presence of scrambled RNA $(n=4)$ or siRNA against SURF-4 $(50 \mathrm{nM})(n=5)$ in combination with oxLDL $(20 \mu \mathrm{M})$ for $24 \mathrm{~h}$. Statistical analysis was performed by unpaired t-test. ${ }^{*} p<0.05$. c Load free cell shortening of adult rat cardiomyocytes that were incubated for $24 \mathrm{~h}$ with oxLDL $(20 \mu \mathrm{M})$ and oxLDL $(20 \mu \mathrm{M})+$ siRNA against SURF-4 $(50 \mathrm{nM})$. Expressed as $\Delta \mathrm{L} / \mathrm{L}(\%)$ as well as (d) contraction velocity $(\mu \mathrm{m} / \mathrm{s})$ and e relaxation velocity $(\mu \mathrm{m} / \mathrm{s}) . n=110$ and 101 cells $(10-12$ independent experiments with an intraassay variability of $p>0.05$ ). Statistical analysis was performed by unpaired t-test for (c) as well as Mann-Whitney test for (d) and (e). $* p \leq 0.05$. Data are mean $\pm \mathrm{SD}$

Under oxLDL incubation PCSK9 was increased in a concentration-dependent manner. In addition we found that SURF-4, that has shown to be important for PCSK9 secretion [10, 32], is expressed in cardiomyocytes and that silencing of SURF-4 improves cardiomyocyte function when incubated with oxLDL. Furthermore we could block the oxLDL-induced reduction in cell shortening by alirocumab as well as Pep 2-8 while the inhibitors had no effect on basal cardiac function. This leads to the suggestion that oxLDL induces PCSK9 release and PCSK9 acts in an autocrine way to reduce cardiomyocyte function.

As exogenously added PCSK9 but also endogenous PCSK9 (rat PCSK9) has direct negative effects on 


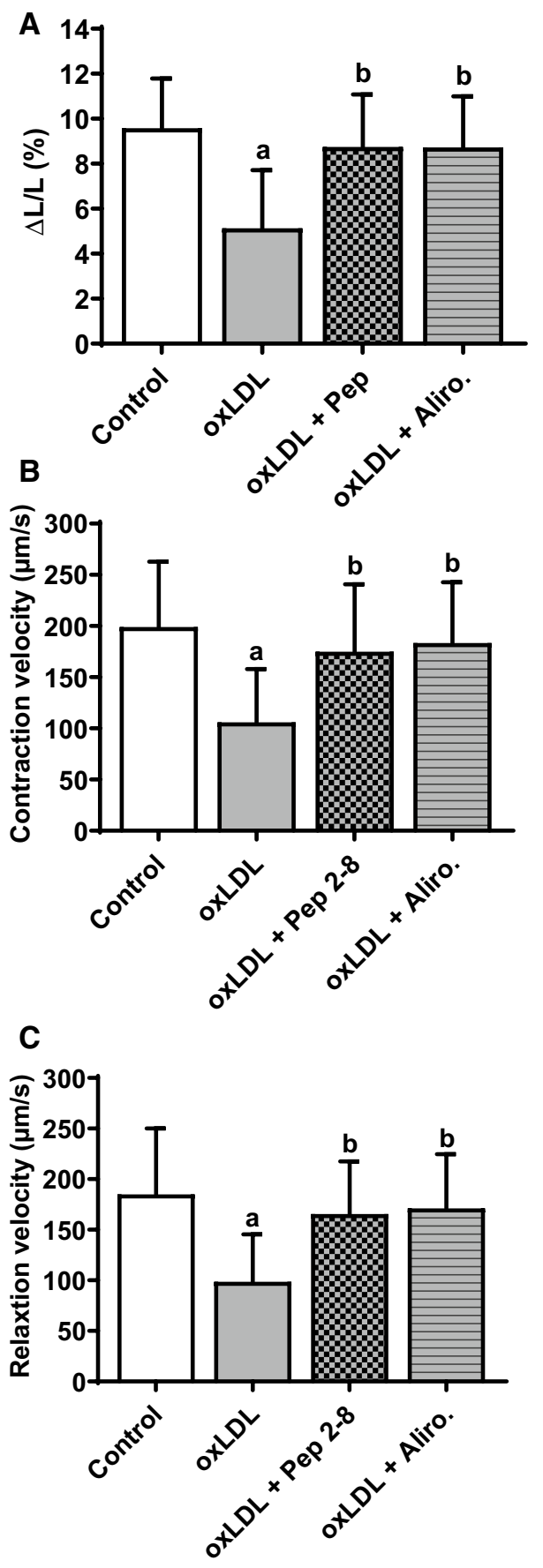

Fig. 7 Effect of oxLDL on cell shortening in the presence of Pep 2-8 and alirocumab. Adult rat ventricular cardiomyocytes were cultured under serum-free conditions and incubated with oxLDL $(20 \mu \mathrm{M})$, and combinations of oxLDL with the PCSK9 inhibitor Pep 2-8 (10 $\mu \mathrm{M})$ or the monoclonal PCSK9 antibody alirocumab $(1.5 \mathrm{mg} / \mathrm{ml})$ respectively. After $24 \mathrm{~h}$, load free cell shortening was determined (cells were paced at $2 \mathrm{~Hz}$ ) and is expressed as (a) $\Delta \mathrm{L} / \mathrm{L} \mathrm{( \% ),} \mathrm{(b)} \mathrm{contrac-}$ tion velocity $(\mu \mathrm{m} / \mathrm{s})$ and $\mathbf{c}$ relaxation velocity $(\mu \mathrm{m} / \mathrm{s})$ of Control $=198$, oxLDL $=198, \quad$ oxLDL + Pep $=90$ and oxLDL + Aliro. $=142$ cells (16-22 independent experiments with an intraassay variability of $p>0.05$ ). Statistical analysis was performed by one-way ANOVA and Student-Newman-Keuls for post hoc analysis. $a \leq 0.05$ vs. Control, oxLDL + Pep $2-8$ and oxLDL + Aliro., $b \leq 0.05$ vs. oxLDL and Control. Data are mean \pm SD
A

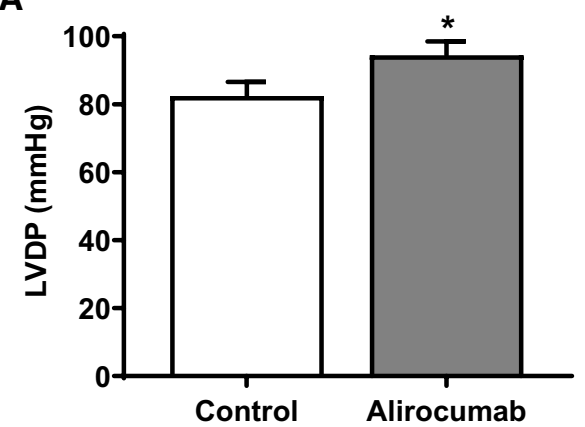

B

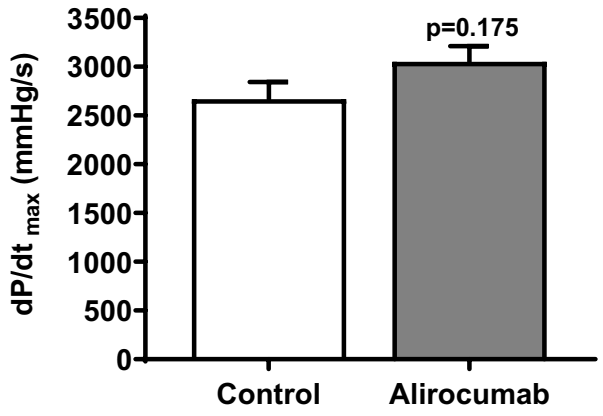

C

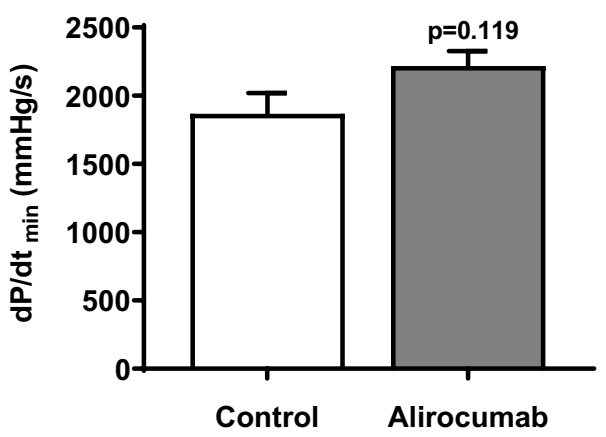

Fig. 8 Effect of PCSK9 antibody alirocumab on basal cardiac function of isolated perfused rat hearts. Hearts from adult Wistar rats were isolated and transferred to a Langendorff perfusion system. Control hearts were perfused with pure buffer while another group was perfused with buffer containing alirocumab $(750 \mu \mathrm{g} / \mathrm{ml})$. a Left ven-

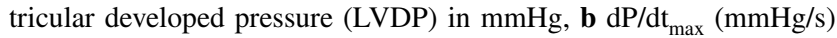

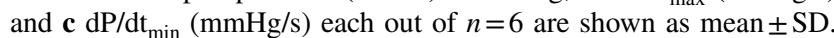
Statistical analysis was performed by unpaired $t$ test. * $p \leq 0.05$

cardiomyocyte function, the domain of PCSK9 that induces the reduction of cardiomyocyte cell shortening must lie in the conserved region between human and rat PCSK9. Overall, the total sequence identity of PCSK9 between these two species is about 77\% [14]. Moreover the PCSK9 induced decline of cardiomyocyte function can be antagonized by Pep 2-8 which is known to inhibit the catalytic domain of PCSK9 that is responsible for LDL-R binding [16, 21, 38]. Therefore the catalytic domain might also be important for the abovementioned PCSK9 effect on cardiomyocyte function. 

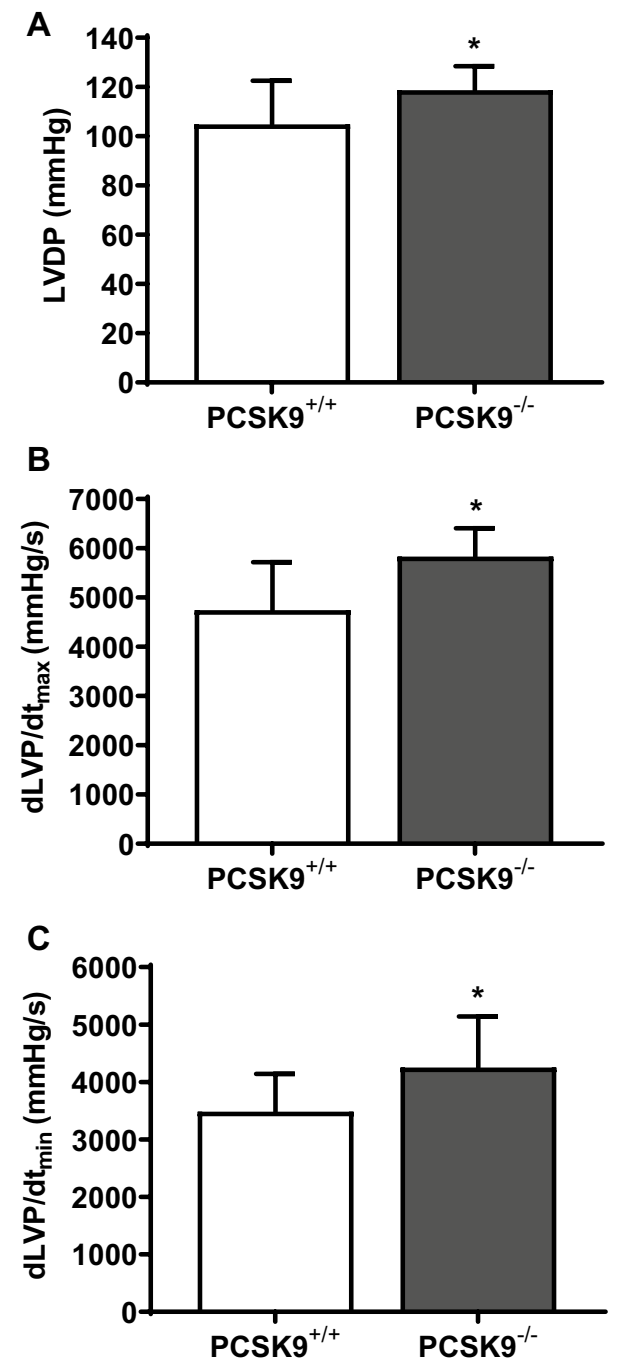

Fig. 9 Effect of PCSK9 knockout on basal cardiac function of isolated and perfused mice hearts. Hearts from PCSK $9^{-1-}$-mice were isolated and transferred to a Langendorff perfusion system. a Left ventricular developed pressure (LVDP) in $\mathrm{mmHg}(n=12)$, b dLVP/ $\mathrm{dt}_{\max }(\mathrm{mmHg} / \mathrm{s})(n=13)$ and $\mathbf{c} \mathrm{dLVP}_{\mathrm{dt}}{ }_{\min }(\mathrm{mmHg} / \mathrm{s})(n=13)$ (at the beginning of the stabilization phase) are shown as mean \pm SD. Statistical analysis was performed by unpaired $t$-test for (a) and (b) as well as Mann-Whitney test for (c). $* p \leq 0.05$

On the organ level we found that hearts isolated from PCSK9 knockout mice show increased basal cardiac function. In addition a cardiac release of PCSK9 was demonstrated under basal conditions in isolated rat hearts. Furthermore the antagonism of PCSK9 with alirocumab led to an immediate increase in left ventricular function. This is the first report about a direct effect of PCSK9 antagonism on basal cardiac function. Moreover, I/R of isolated mice hearts resulted in an increased expression of PCSK9 in left ventricles. In addition, hearts isolated from PCSK9 knockout mice showed increased postischemic left venctricular
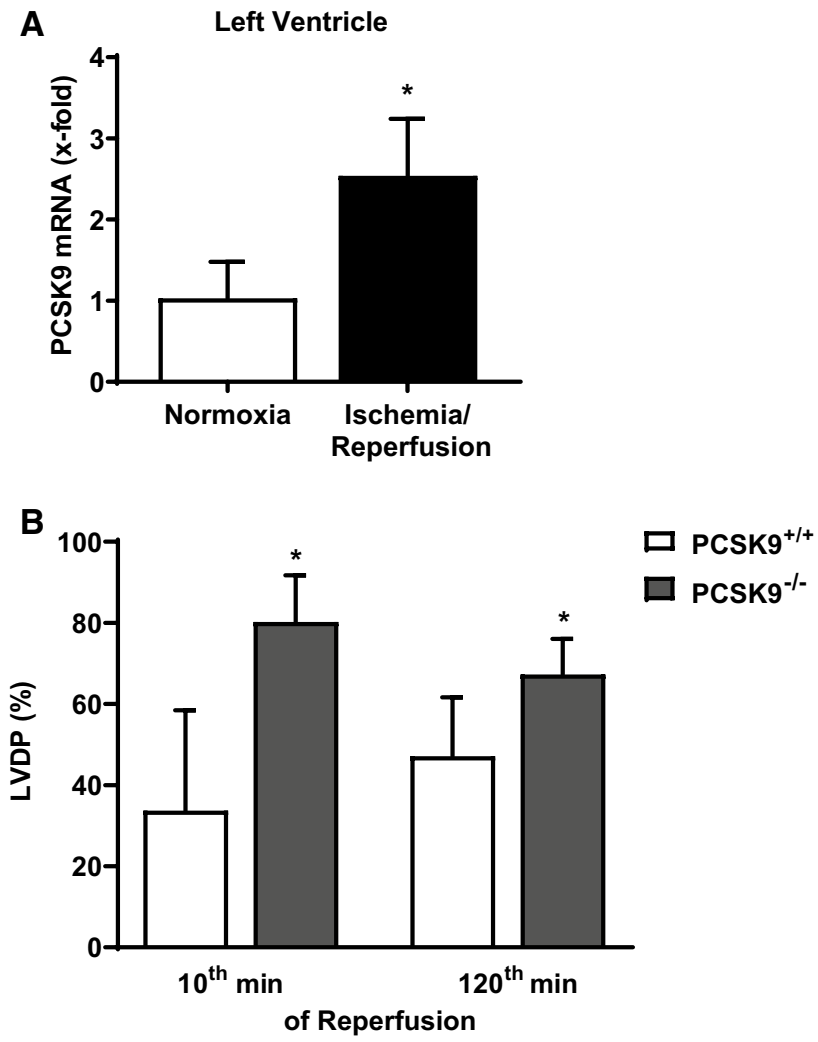

Fig. 10 PCSK9 expression in ischemic mice hearts as well as left ventricular function of PCSK9 knockout hearts. a Hearts from C57BL6/JR mice were excised and exposed to $45 \mathrm{~min}$ of ischemia and $120 \mathrm{~min}$ reperfusion (I/R) or $165 \mathrm{~min}$ normoxia (Nx). PCSK9 mRNA expression of left ventricles was analyzed and normalized to the mean expression of B2M, HPRT and GAPDH. Nx: $n=10, \mathrm{I} / \mathrm{R}$ : $n=9$. Statistical analysis was performed by unpaired $t$-test. ${ }^{*} p \leq 0.05$. b Left ventricular developed pressure (LVDP) of the 10th minute as well as of the 120th minute of reperfusion from isolated hearts $\left(\mathrm{PCSK}^{-/-}\right.$- and $\mathrm{PCSK}^{+/+}$-mice) was measured and normalized to the LVDP under basal conditions (given in \%). $n=11-13$. Statistical analysis was performed by unpaired $t$-test. $* p \leq 0.05$. All data are mean $\pm \mathrm{SD}$

function and therefore an improved recovery after suffering from myocardial ischemia. So far an increased expression of PCSK9 in mice hearts, which have been subjected to acute ischemia/reperfusion (present study), myocardial ischemia for 1 week, as well as in human hearts with recent infarcts, was found [9]. Furthermore, it was shown that increased PCSK9 expression in hypoxic neonatal mouse cardiomyocytes is mediated by Hypoxia inducible factor-1 alpha (HIF-1 $\alpha$ ) [9]. Moreover a correlation between the amount of PCSK9 in the zone bordering the infarcted area and left ventricular function ( 1 week of left coronary artery occlusion) was observed [9]. In addition, PCSK9 inhibitors have been shown to improve cardiac function in rats with acute $\mathrm{I} / \mathrm{R}$ injury when applied prior 
to ischemia [26]. Finally a clinical study reports a correlation between high PCSK9 plasma levels and a reduction of left ventricular ejection fraction in patients that suffered from ST-segment elevation myocardial infarction [24]. These studies demonstrate, similar to our findings, a positive effect of PCSK9 inhibition or genetic deletion on cardiac function after ischemia or I/R injury in vivo [9, 26]. Although in vivo models enable to study the effect of PCSK9 inhibition in a more complex way than ex vivo models they do not allow to distinguish between systemic and cardiac derived PCSK9.

Based on the experiments performed on isolated cardiomyocytes it could be hypothesized that also on the organ level, PCSK9 that is released from, e.g., cardiomyocytes acts in an autocrine way to reduce cardiac function. An increased PCSK9 secretion, that requires SURF-4, can be triggered by oxLDL. The exact mechanisms of PCSK9 mediated impaired cardiomyocyte/myocardial function and in this context binding/interaction partner of PCSK9 in cardiomyocytes have to be identified. Here a modulation of autophagy of cardiomyocytes mediated by PCSK9 could play a role $[9,37]$.

In conclusion, this study improves our current understanding about the relationship between high plasma levels of PCSK9 and cardiac function as well as our understanding about the mechanism by which drugs increasing cardiac expression of PCSK9 might affect cardiac function.

Acknowledgements We thank Nadine Woitasky, Peter Volk and Martin Heisler for excellent technical support. The study is part of thesis of A. Wolf.

Funding Open Access funding enabled and organized by Projekt DEAL. The study was funded in part by a research grant from Sanofi. Prof. Dr. Rainer Schulz received honoraria from Amgen, Recordati and Sanofi for lecturing.

\section{Compliance with ethical standards}

Conflict of interest On behalf of all authors, the corresponding author states that there is no conflict of interest.

Open Access This article is licensed under a Creative Commons Attribution 4.0 International License, which permits use, sharing, adaptation, distribution and reproduction in any medium or format, as long as you give appropriate credit to the original author(s) and the source, provide a link to the Creative Commons licence, and indicate if changes were made. The images or other third party material in this article are included in the article's Creative Commons licence, unless indicated otherwise in a credit line to the material. If material is not included in the article's Creative Commons licence and your intended use is not permitted by statutory regulation or exceeds the permitted use, you will need to obtain permission directly from the copyright holder. To view a copy of this licence, visit http://creativecommons .org/licenses/by/4.0/.

\section{References}

1. Abdullah SM, Defina LF, Leonard D, Barlow CE, Radford NB, Willis BL, Rohatgi A, McGuire DK, de Lemos JA, Grundy SM, Berry JD, Khera A (2018) Long-term association of low-density lipoprotein cholesterol with cardiovascular mortality in individuals at low 10-year risk of atherosclerotic cardiovascular disease. Circulation 138:2315-2325. https://doi.org/10.1161/CIRCU LATIONAHA.118.034273

2. Abifadel M, Varret M, Rabès J-P, Allard D, Ouguerram K, Devillers M, Cruaud C, Benjannet S, Wickham L, Erlich D, Derré A, Villéger L, Farnier M, Beucler I, Bruckert E, Chambaz J, Chanu B, Lecerf J-M, Luc G, Moulin P, Weissenbach J, Prat A, Krempf M, Junien C, Seidah NG, Boileau C (2003) Mutations in PCSK9 cause autosomal dominant hypercholesterolemia. Nat Genet 34:154-156. https://doi.org/10.1038/ng1161

3. Amput P, McSweeney C, Palee S, Phrommintikul A, Chattipakorn SC, Chattipakorn N (2019) The effects of proprotein convertase subtilisin/kexin type 9 inhibitors on lipid metabolism and cardiovascular function. Biomed Pharmacother 109:1171-1180. https:// doi.org/10.1016/j.biopha.2018.10.138

4. Benn M, Nordestgaard BG, Grande P, Schnohr P, TybjaergHansen A (2010) PCSK9 R46L, low-density lipoprotein cholesterol levels, and risk of ischemic heart disease: 3 independent studies and meta-analyses. J Am Coll Cardiol 55:2833-2842. https ://doi.org/10.1016/j.jacc.2010.02.044

5. Bøtker HE, Hausenloy D, Andreadou I, Antonucci S, Boengler K, Davidson SM, Deshwal S, Devaux Y, Di Lisa F, Di Sante M, Efentakis P, Femminò S, García-Dorado D, Giricz Z, Ibanez B, Iliodromitis E, Kaludercic N, Kleinbongard P, Neuhäuser M, Ovize M, Pagliaro P, Rahbek-Schmidt M, Ruiz-Meana M, Schlüter K-D, Schulz R, Skyschally A, Wilder C, Yellon DM, Ferdinandy P, Heusch G (2018) Practical guidelines for rigor and reproducibility in preclinical and clinical studies on cardioprotection. Basic Res Cardiol 113:39. https://doi.org/10.1007/s00395-018-0696-8

6. Chaudhary R, Garg J, Shah N, Sumner A (2017) PCSK9 inhibitors: a new era of lipid lowering therapy. World J Cardiol 9:76-91. https://doi.org/10.4330/wjc.v9.i2.76

7. Cohen JC, Boerwinkle E, Mosley TH, Hobbs HH (2006) Sequence variations in PCSK9, low LDL, and protection against coronary heart disease. N Engl J Med 354:1264-1272. https://doi. org/10.1056/NEJMoa054013

8. Da Dalt L, Ruscica M, Bonacina F, Balzarotti G, Dhyani A, Di Cairano E, Baragetti A, Arnaboldi L, de Metrio S, Pellegatta F, Grigore L, Botta M, Macchi C, Uboldi P, Perego C, Catapano AL, Norata GD (2019) PCSK9 deficiency reduces insulin secretion and promotes glucose intolerance: the role of the low-density lipoprotein receptor. Eur Heart J 40:357-368. https://doi.org/10.1093/ eurheartj/ehy357

9. Ding Z, Wang X, Liu S, Shahanawaz J, Theus S, Fan Y, Deng X, Zhou S, Mehta JL (2018) PCSK9 expression in the ischaemic heart and its relationship to infarct size, cardiac function, and development of autophagy. Cardiovasc Res 114:1738-1751. https ://doi.org/10.1093/cvr/cvy128

10. Emmer BT, Hesketh GG, Kotnik E, Tang VT, Lascuna PJ, Xiang J, Gingras A-C, Chen X-W, Ginsburg D (2018) The cargo receptor SURF4 promotes the efficient cellular secretion of PCSK9. Elife. https://doi.org/10.7554/eLife.38839

11. Gao S, Liu J (2017) Association between circulating oxidized low-density lipoprotein and atherosclerotic cardiovascular disease. Chronic Dis Transl Med 3:89-94. https://doi.org/10.1016/j. cdtm.2017.02.008

12. Glerup S, Schulz R, Laufs U, Schlüter K-D (2017) Physiological and therapeutic regulation of PCSK9 activity in cardiovascular 
disease. Basic Res Cardiol 112:32. https://doi.org/10.1007/s0039 5-017-0619-0

13. Gu HM, Zhang DW (2015) Hypercholesterolemia, low density lipoprotein receptor and proprotein convertase subtilisin/kexintype 9. J Biomed Res 29:356-361. https://doi.org/10.7555/ JBR.29.20150067

14. Gustafsen C, Olsen D, Vilstrup J, Lund S, Reinhardt A, Wellner N, Larsen T, Andersen CBF, Weyer K, Li JP, Seeberger PH, Thirup S, Madsen P, Glerup S (2017) Heparan sulfate proteoglycans present PCSK9 to the LDL receptor. Nat Commun 8:503. https://doi. org/10.1038/s41467-017-00568-7

15. Hartley JL, Temple GF, Brasch MA (2000) DNA cloning using in vitro site-specific recombination. Genome Res 10:1788-1795. https://doi.org/10.1101/gr.143000

16. Kwon HJ, Lagace TA, McNutt MC, Horton JD, Deisenhofer J (2008) Molecular basis for LDL receptor recognition by PCSK9. Proc Natl Acad Sci USA 105:1820-1825. https://doi.org/10.1073/ pnas.0712064105

17. Landy A (1989) Dynamic, structural, and regulatory aspects of lambda site-specific recombination. Annu Rev Biochem 58:913949. https://doi.org/10.1146/annurev.bi.58.070189.004405

18. Langer M, Lüttecke D, Schlüter K-D (2003) Mechanism of the positive contractile effect of nitric oxide on rat ventricular cardiomyocytes with positive force/frequency relationship. Pflugers Arch 447:289-297. https://doi.org/10.1007/s00424-003-1187-8

19. Law MR, Wald NJ, Rudnicka AR (2003) Quantifying effect of statins on low density lipoprotein cholesterol, ischaemic heart disease, and stroke: systematic review and meta-analysis. BMJ 326:1423. https://doi.org/10.1136/bmj.326.7404.1423

20. Livak KJ, Schmittgen TD (2001) Analysis of relative gene expression data using real-time quantitative PCR and the 2(-Delta Delta C(T)) Method. Methods 25:402-408. https://doi.org/10.1006/ meth.2001.1262

21. Lo Surdo P, Bottomley MJ, Calzetta A, Settembre EC, Cirillo A, Pandit S, Ni YG, Hubbard B, Sitlani A, Carfí A (2011) Mechanistic implications for LDL receptor degradation from the PCSK9/ LDLR structure at neutral pH. EMBO Rep 12:1300-1305. https ://doi.org/10.1038/embor.2011.205

22. Mach F, Baigent C, Catapano AL, Koskinas KC, Casula M, Badimon L, Chapman MJ, de Backer GG, Delgado V, Ference BA, Graham IM, Halliday A, Landmesser U, Mihaylova B, Pedersen TR, Riccardi G, Richter DJ, Sabatine MS, Taskinen M-R, Tokgozoglu L, Wiklund O (2019) 2019 ESC/EAS Guidelines for the management of dyslipidaemias: lipid modification to reduce cardiovascular risk. Eur Heart J 41:111-188. https://doi.org/10.1093/ eurheartj/ehz455

23. Mbikay M, Sirois F, Mayne J, Wang G-S, Chen A, Dewpura T, Prat A, Seidah NG, Chretien M, Scott FW (2010) PCSK9-deficient mice exhibit impaired glucose tolerance and pancreatic islet abnormalities. FEBS Lett 584:701-706. https://doi.org/10.1016/j. febslet.2009.12.018

24. Miñana G, Núñez J, Bayés-Genís A, Revuelta-López E, RíosNavarro C, Núñez E, Chorro FJ, López-Lereu MP, Monmeneu JV, Lupón J, Sanchis J, Bodí V (2020) Role of PCSK9 in the course of ejection fraction change after ST-segment elevation myocardial infarction: a pilot study. ESC Heart Fail. https://doi.org/10.1002/ ehf 2.12533

25. Nippert F, Schreckenberg R, Schlüter K-D (2017) Isolation and cultivation of adult rat cardiomyocytes. J Vis Exp. https://doi. org/10.3791/56634

26. Palee S, McSweeney CM, Maneechote C, Moisescu DM, Jaiwongkam T, Kerdphoo S, Chattipakorn SC, Chattipakorn N (2019)
PCSK9 inhibitor improves cardiac function and reduces infarct size in rats with ischaemia/reperfusion injury: benefits beyond lipid-lowering effects. J Cell Mol Med 23:7310-7319. https://doi. org/10.1111/jcmm.14586

27. Pott J, Schlegel V, Teren A, Horn K, Kirsten H, Bluecher C, Kratzsch J, Loeffler M, Thiery J, Burkhardt R, Scholz M (2018) Genetic regulation of PCSK9 (proprotein convertase subtilisin/ kexin type 9) plasma levels and its impact on atherosclerotic vascular disease phenotypes. Circ Genom Precis Med. https://doi. org/10.1161/CIRCGEN.117.001992

28. Schlüter K-D, Wolf A, Weber M, Schreckenberg R, Schulz R (2017) Oxidized low-density lipoprotein (oxLDL) affects loadfree cell shortening of cardiomyocytes in a proprotein convertase subtilisin/kexin 9 (PCSK9)-dependent way. Basic Res Cardiol 112:63. https://doi.org/10.1007/s00395-017-0650-1

29. Schreckenberg R, Rebelo M, Deten A, Weber M, Rohrbach S, Pipicz M, Csonka C, Ferdinandy P, Schulz R, Schlüter K-D (2015) Specific mechanisms underlying right heart failure: the missing upregulation of superoxide dismutase- 2 and its decisive role in antioxidative defense. Antioxid Redox Signal 23:1220-1232. https ://doi.org/10.1089/ars.2014.6139

30. Schreckenberg R, Maier T, Schlüter K-D (2009) Post-conditioning restores pre-ischaemic receptor coupling in rat isolated hearts. Br J Pharmacol 156:901-908. https://doi.org/10.111 1/j.1476-5381.2008.00053.x

31. Schulz R, Schlüter K-D, Laufs U (2015) Molecular and cellular function of the proprotein convertase subtilisin/kexin type 9 (PCSK9). Basic Res Cardiol 110:4. https://doi.org/10.1007/s0039 5-015-0463-Z

32. Seidah NG, Prat A, Pirillo A, Catapano AL, Norata GD (2019) Novel strategies to target proprotein convertase subtilisin kexin 9: beyond monoclonal antibodies. Cardiovasc Res 115:510-518. https://doi.org/10.1093/cvr/cvz003

33. Seidah NG, Benjannet S, Wickham L, Marcinkiewicz J, Jasmin SB, Stifani S, Basak A, Prat A, Chretien M (2003) The secretory proprotein convertase neural apoptosis-regulated convertase 1 (NARC-1): liver regeneration and neuronal differentiation. Proc Natl Acad Sci USA 100:928-933. https://doi.org/10.1073/ pnas.0335507100

34. Sharotri V, Collier DM, Olson DR, Zhou R, Snyder PM (2012) Regulation of epithelial sodium channel trafficking by proprotein convertase subtilisin/kexin type 9 (PCSK9). J Biol Chem 287:19266-19274. https://doi.org/10.1074/jbc.M112.363382

35. Tsutsui T, Tsutamoto T, Wada A, Maeda K, Mabuchi N, Hayashi M, Ohnishi M, Kinoshita M (2002) Plasma oxidized low-density lipoprotein as a prognostic predictor in patients with chronic congestive heart failure. J Am Coll Cardiol 39:957-962. https://doi. org/10.1016/S0735-1097(02)01721-7

36. Xu R-X, Liu J, Li XL, Li S, Zhang Y, Jia YJ, Sun J, Li JJ (2015) Impacts of ezetimibe on PCSK9 in rats: study on the expression in different organs and the potential mechanisms. J Transl Med 13:87. https://doi.org/10.1186/s12967-015-0452-x

37. Yurtseven E, Ural D, Baysal K, Tokgözoğlu L (2020) An update on the role of PCSK9 in Atherosclerosis. J Atheroscler Thromb. https://doi.org/10.5551/jat.55400(Epub ahead of print. PMID: 32713931)

38. Zhang Y, Eigenbrot C, Zhou L, Shia S, Li W, Quan C, Tom J, Moran P, Di Lello P, Skelton NJ, Kong-Beltran M, Peterson A, Kirchhofer D (2014) Identification of a small peptide that inhibits PCSK9 protein binding to the low density lipoprotein receptor. J Biol Chem 289:942-955. https://doi.org/10.1074/jbc.M113.51406 